\title{
Catalysis by Pillared Layered Double Hyfroxides
}

\author{
E Butenko* and A Kapustin \\ Priazovskiy State Technical University, Ukraine \\ *Corresponding author: E Butenko, Priazovskiy State Technical University, Ukraine
}

\begin{tabular}{|c|c|}
\hline ARTICLE INFO & ABSTRACT \\
\hline $\begin{array}{l}\text { Received: 豐 October 01, } 2019 \\
\text { Published: 慧 October 15, } 2019\end{array}$ & $\begin{array}{l}\text { Citation: E Butenko, A Kapustin. Catalysis by Pillared Layered Double Hyfroxides. Bi- } \\
\text { omed J Sci \& Tech Res 22(1)-2019. BJSTR. MS.ID.003681. }\end{array}$ \\
\hline
\end{tabular}

\section{Short Communication}

The motto of a modern chemical production is "the best solvent is the absence of the solvent". And these problems can be solved with the use of heterogeneous catalysts. However, there is a huge group of a processes carried out under the conditions of the basic catalysts, for example condensation, alkylation ethoxylation and many others. The attempts to replace homogeneous bases with solid ion-exchange resins appeared unsuccessful, since they are unstable at elevated temperature and synergistic degradation is observed under the influence of temperature and reaction medium. Layered Double Hydroxides is a class of inorganic compounds consisting of positively charged layers of metal hyroxides, as well as anions and solvent molecules in the interplanar space [1]. Hydroxides form a system of octahedral cavities, statistically filled with cations of metals of different valencies. LDHs can capture and exchange both organic and inorganic anions and cations, and these properties make these catalysts unique.

The most important property, thanks to which LDH surpasses all other basic catalysts, is the ability to control the pore size. This allows to create structures corresponding to the sizes of molecules, that is, to create narrow-selective catalysts. Pillared clays are twodimensional LDHs with a given size of interlayered distances. Creating columns fixed the distance between layers. Pillared LDHs allow to development of catalysts that are selective for different isomers. For example, we can obtain 1,4-product at hydrogenation of conjugated dienes. Or we can obtain selectively cis-butene by changing the inner space in LDH during isomerization 1-butene to 2-butene [2].

Located in the inner space of LDHs molecules change their orientation, releasing the blocked active sites. We compare the sorption of $\beta$-naphthol and naphthalene. After sorption, the specific surface was determined and the interplanar distances were measured. The interplanar distance in LDHs is about $7 \AA$. This value is comparable to the "thickness" of the aromatic ring of about $3 \AA$, whereas the diameter of the benzene molecule is $7 \AA$. And for $\beta$-naphthol, the plane-parallel arrangement is observed only in the initial stage of ion exchange [3]. When the aromatic rings of naphthalene are arranged parallel to the inorganic layers, the interplanar distance is $9 \AA$ and at perpendicular position is $19 \AA$.

\section{References}

1. Kapustin AE (1992) Structure and basic properties of layered double hydroxides. Chemistry and Chemical Technology 35: 40-42.

2. Kapustin A (2008) Basic Heterogeneous Catalysis. Renata pp. 308.

3. Butenko EO, Kapustin AE, Gromilov SA (2011) Changes in the structure of $\mathrm{Mg} \mathrm{x} \mathrm{Al} \mathrm{y}(\mathrm{OH}) \mathrm{z}$ layered double hydroxides during the adsorption of organic compounds. J Struct Chem 52(2): 436-438. 
ISSN: 2574-1241

DOI: $10.26717 /$ BJSTR.2019.22.003681

E Butenko. Biomed J Sci \& Tech Res

(c) (i) This work is licensed under Creative

Submission Link: https://biomedres.us/submit-manuscript.php

$\begin{array}{ll}\text { BIOMEDICAL } & \text { Assets of Publishing with us } \\ \text { RESEARCHES } & \text { Global archiving of articles } \\ & \text { - Immediate, unrestricted online access } \\ \end{array}$

